
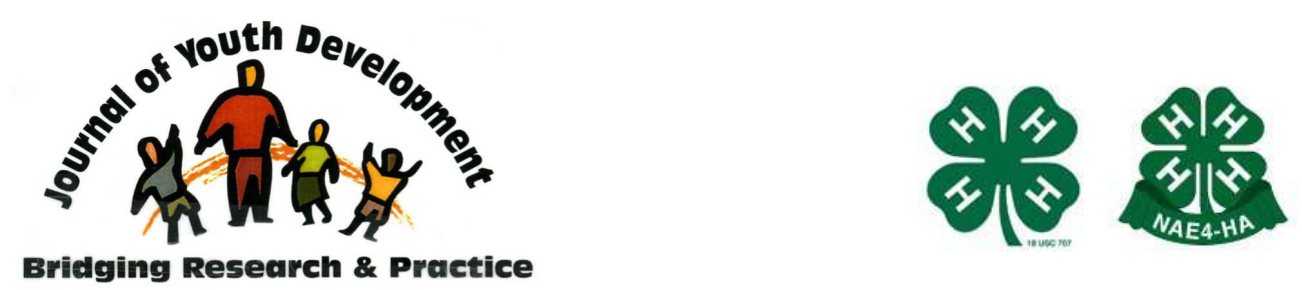

\title{
Fostering Youth Engagement on Community Teams
}

Julie A. Scheve, M.Ed.

Girl Scouts of the Sierra Nevada

Reno, NV

j.scheve@gssn.org

Dr. Daniel F. Perkins

Agricultural and Extension Education

The Pennsylvania State University

University Park, PA

dfp102@psu.edu

Dr. Claudia C. Mincemoyer

Agricultural and Extension Education

The Pennsylvania State University

University Park, PA

cmincemoyer@psu.edu 


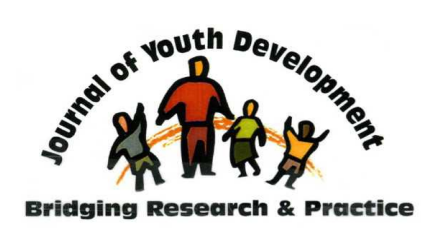

Volume 1, Number 1, Spring 2006

\title{
JOURNAL OF YOUTH DEVELOPMENT
}

bridging research and practice

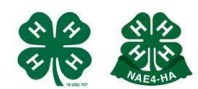

Article 0101PA003

\section{Fostering Youth Engagement on Community Teams}

Julie A. Scheve

Girl Scouts of America

Daniel F. Perkins and Claudia C. Mincemoyer

The Pennsylvania State University

\begin{abstract}
Within the youth development field a growing movement exists to establish youth member positions on community teams (e.g. organizational boards and planning committees). The involvement of youth on decision-making teams is commonly referred to as youth engagement. As a relatively new approach to youth and community development, the existing research shows the potential positive impacts youth engagement efforts may produce and encourages youth practitioners to incorporate such efforts into their programs and organizations. In doing so, successful youth engagement efforts may be sustained within teams that best adapt their organizational structure, policies, and practices to complement the developmental needs of youth. Such adaptations begin with the four team characteristics presented in this paper: adult support, a youth-friendly environment, opportunities to complete meaningful tasks, and opportunities to learn and use new skills. When these practices are woven through the work of the team, youth engagement may flourish.
\end{abstract}

\section{Introduction}

Within the youth development field, a growing movement exists to establish youth member positions on community teams (e.g. organizational boards and planning committees). The involvement of youth on community teams is commonly referred to as youth engagement. As team members, youth receive the same or similar responsibilities as adults, such as voting privileges. 
Providing youth engagement opportunities allow youth to contribute to their own development by learning and applying life skills. In addition, youth contribute to the development of their communities by designing solutions to address local issues (Curnan \& Hughes, 2002; Irby, et al., 2001; Perkins, Borden, Keith, Hoope-Rooney, \& Villarruel, 2003). In related studies within the field of education, researchers have found that students improve academically when teachers provide youth with opportunities to work with them to improve curriculum and instruction (Oldfather, 1995; Rudduck \& Futter, 2000), that is, when students are engaged. Such experiences can be a catalyst for youth's sense of belonging within a community (Cargo, et al., 2003) and civic awareness (Flanagan \& Van Horn, 2003). Adults and organizations involved in youth engagement efforts receive benefits as well. Adults may feel reenergized and committed to the team while programs become more attuned to the needs of program participants (Zeldin, McDaniel, Topitzes, \& Calvert, 2000).

The community youth development (CYD) framework promotes youth engagement opportunities as a viable avenue for healthy youth and community development. CYD incorporates the developmental assets of positive youth development (Benson, 1997; Lerner, 2004), while also emphasizing youth-adult partnerships to create social change (Camino \& Zeldin, 2002).

Perkins and colleagues (2003) define CYD as: purposely creating environments that provide constructive, affirmative, and encouraging relationships that are sustained over time with adults and peers, while concurrently providing an array of opportunities that enable youth to build their competencies and become engaged as partners in their own development as well as the development of their communities (p.6).

The CYD framework views youth as active participants that can and should contribute to families, schools, organizations, and communities. Youth should not be thought of as future leaders, but rather as leaders of today who deserve a voice in the decisions that affect their lives and communities (Perkins, et al., 2003).

\section{Community Team Characteristics that Foster Youth Engagement}

A review of the literature led to the identification of four salient team characteristics that seem to be directly linked to successful youth engagement efforts. Foremost, genuine adult support of youth engagement among members is crucial to initiating and sustaining such an effort. Second, a youth-friendly environment is needed to encourage youth to be fully engaged. Third, youth must be involved in meaningful tasks that advance team goals. Finally, youth need opportunities to learn and use new skills that enable them to build competences. Youth engagement efforts, in the presence of these team characteristics, give youth a sense of 'mattering' in their communities, which Eccles \& Gootman (2002) highlighted as one feature of positive developmental settings (p.103).

\section{Adult Support}

The first step to engaging youth on community teams is to build support among adult members. Vital to this step is the existence of a strong advocate on the team for youth engagement who can generate awareness and build consensus among other team members (Checkoway, et al., 2003). Inviting youth to the table requires a paradigm shift of how youth are viewed by adults. Traditionally, society has limited the roles available to youth (e.g., students, athletes, and consumers) (Camino \& Zeldin, 2002). Contrary to those traditional roles, adults supportive of youth engagement provide youth access to an array of community roles 
including advisor, planner, decision-maker, implementer, and evaluator. The CYD framework promotes such roles for young people which enable youth to work alongside adults to improve the quality of life in their communities (Curnan \& Hughes, 2002).

Adults may demonstrate their support for youth through their actions. Supportive adults show youth respect and equality (Camino, 2002a). In other words, adults work with youth and not for youth. However, Camino (2000b) cautions that "being equal does not necessarily mean being the same" (p. 28). Adults and youth working together must acknowledge the strengths and weaknesses of the other person. Youth have limited experience and resources to achieve goals on their own. They need guidance from adults. Youth benefit from adults who have a broad range of experiences and access to institutional power (Camino, 2000a; O'Donoghue, Kirshner, \& McLaughlin, 2002).

Adults receive benefits from working in partnership with youth as well. They can feel reenergized by young people's enthusiasm and passion for a cause (Zeldin, et al., 2000). Through their relationships with young people, adults may also be exposed to more nontraditional ideas resulting from young people's unique perspective. This partnership between youth and adults is based on mutuality, respect, and reciprocity (Hughes \& Curnan, 2000; Jones, 2004); such a relationship is the foundation of CYD.

Supportive adults articulate to youth the expectations, responsibilities, and time commitment necessary to be a team member (Fiscus, 2003). Without a clearly defined role, youth may become confused about their purpose and value to the team. To avoid this, adults can create a job description or list of responsibilities and review it with youth members. Supportive adults establish open lines of communication with youth members' parents; discussing their child's responsibilities as a team member and answering questions they may have about their child's involvement on the team (Bernard, 2004). Supportive adults seek out the ideas and suggestions of youth during team meetings by encouraging them to participate in the discussion (Mueller, Wunrow, \& Einspruch, 2000). Especially in the beginning, youth may feel uncomfortable speaking in front of a large group. Therefore, it is essential for adults to ask youth specific questions during a meeting or talk with them afterwards to get their opinions and answer questions. In addition, supportive adults regularly schedule time to reflect with youth about their role on the team; this may occur after a team meeting or during a phone call. (Kahne, Honig, \& Mclaughlin, 1998). Fiscus (2003) recommends the identification of an adult mentor for each youth member to ensure that youth receive ample support while participating on the team.

\section{Youth-friendly Environment}

Adults committed to CYD believe "young people are capable, competent members of society whose voices and opinions are valuable" (Yohalem, 2003, p. 376). To affirm such beliefs, adults need to create an inclusive environment that not only welcomes but also appreciates youth. Community teams need an intentional structure that facilitates positive youth-adult interaction (Jekielek, Moore, Hair, \& Scarupa, 2002). In doing so, it is necessary to identify, acknowledge, and remove organization barriers that stand in the way of youth engagement.

Examples of typical organizational barriers to youth engagement include lack of transportation, inconvenient meeting times and locations, and by-laws that prevent youth from voting on issues (Young \& Sazama, 1999). For example, Zeldin (2004) found that youth felt respected when adults made structural improvements that more fully allowed them to participate. One such 
youth felt "appreciated that the board changed the way it conducted board meetings to allow for more time in small groups, informal conversations, and other activities which gave youth time to build relationships" (p. 15).

Addressing organizational barriers that limit youth engagement may be the largest obstacle to overcome; in part, due to adults' attitudes and perceptions of youth, their previous experiences with youth, or their resistance to change. However, if adults remain flexible and committed to involving youth, then the organization and services it offers may greatly benefit.

In addition to removing organizational barriers, it is vital to establish clear and consistent channels of communication between adults and youth (Mueller, et al., 2000). For example, adults should explain acronyms and technical jargon during meetings to prevent confusion and to foster an atmosphere of inclusiveness. Furthermore, adults should solicit youth's ideas and suggestions first during a meeting as a way to limit feelings of intimidation (Mueller, et al., 2000). Solicitation of youth's opinions and suggestions reaffirms adult support of youth engagement. However, genuine youth engagement efforts may be jeopardized if adults listen to but do not act on youth's ideas. According to Fiscus (2003), youth are more likely to remain involved and committed to the team when their opinions are valued by other team members.

\section{Opportunities to Complete Meaningful Tasks}

Hart (1992) cautions that youth engagement efforts may resemble tokenism unless genuine opportunities exist on community teams for youth to make decisions and complete meaningful tasks. According to Mueller and colleagues (2000), youth engagement efforts are more likely to be sustained when adults provide youth with developmentally-appropriate tasks which gradually increase in level of responsibility over time. Therefore, it is necessary to give youth time to learn and grow in their new roles. Depending on the age and skill-level, youth may perform small tasks before being given additional, more complex responsibilities.

An essential tenet in the CYD framework is the transfer of skills between adults and youth (Lane, 1996). This takes place through appropriate guidance and coaching by adults (Camino, 2000a). Adults should assist youth in their responsibilities, with their assistance decreasing as youth's competency and comfort in completing tasks increases. In addition, adults need to foster a team environment where all members are held accountable to their commitments including youth (Mueller, et al., 2000). For example, adults may remind youth of approaching deadlines and request updates on their progress. Upon completion of tasks, adults may schedule a time to reflect with youth about their success and challenges in completing tasks and discuss methods to make improvements for the future (Huebner, 1998). It is important that youth not be deterred by unexpected or disappointing outcomes. Instead, adult mentors should recognize the opportunity as a teachable moment where taking risks and learning how to "fail courageously" are discussed with youth (Perkins \& Borden, 2003, p. 334).

Youth engagement in meaningful tasks is most fruitful when the benefits extend beyond the individual and link him/her to the surrounding community (Pancer, Rose-Krasnor, \& Loiselle, 2002). For example, the San Francisco Department of Children, Youth, and their Families trained and assisted youth in the evaluation of the city's youth-serving programs (Kirshner, O'Donoghue, \& McLaughlin, 2002). Opportunities to address community issues and improve the quality of life for community residents may enhance youth's civic competencies, social networks, and feelings of social responsibility (Checkoway, et al., 2003). Indeed, Mitra (2004) found that students felt a sense of connection and responsibility toward their school when they 
were given a platform for their voices to be heard or as she states, "becoming a critical democratic participant yields a discourse of emotional pride and protection for public institutions" (p. 674).

\section{Opportunities to Learn and Use New Skills}

The CYD framework promotes opportunities where youth can learn and apply new skills to real life situations; thus fostering feelings of mastery and self-efficacy (Perkins, et al., 2003). Such opportunities exist for youth when they are engaged on community teams for sustained periods of time. For example, youth involved in a community health initiative reported learning and using life skills (e.g., teamwork, compromise, perspective-taking, and cooperation) in order to successfully complete the project (Cargo et al., 2003). In fact, such skills proved necessary for the survival and success of the project.

Opportunities to learn and use new skills may help youth develop and refine cognitive and social competencies (Listen, Inc., 2003). Of particular interest may be the development of initiative, which has been shown to be absent in youth's school environment (Larson, 2000). In addition, youth engagement on community teams creates opportunities for young people to learn and use technical skills that can spark an interest in future educational and career pathways. The skills youth acquire through their experiences on community teams may also be transferred to other areas of their lives (e.g., work, family, and peers).

\section{Examples of Youth Engagement on Community Teams}

The Seven Circles Coalition, which strives to prevent drug use among adolescents in southeastern Alaska, is a prime example of successful youth engagement within a community coalition (Wunrow \& Einspruch, 2001). The coalition exists at two levels, local and regional. The local partnerships address prevention needs specific to their communities. The regional office provides training and technical assistance to the local partnerships. One key component of the coalition is to utilize a youth-adult partnership model to conduct prevention programs. To establish successful partnerships adult members created an organizational structure that addresses the needs of youth members.

At the local level, adults value the opinions of youth and solicit their ideas when developing prevention programs. Such actions create a youth-friendly environment and convey a message of adult support for youth engagement. To create opportunities to complete meaningful tasks, the coalition allows youth to take leadership roles in the development, implementation, and evaluation of these programs. For instance, in one community, youth and adults partnered together to open a teen center. Youth played an instrumental role in planning and leading center activities and fundraising efforts which provided them with opportunities to learn and use new skills.

In another community, youth worked with adults to establish a skate board park. Initially, such tasks included securing buy-in from community residents, fundraising, designing, and constructing the park. After the skate park was built, youth formed a Skate Board to organize skill building clinics and competitions.

At the regional level, two paid youth positions exist to complement the three paid adult positions; further conveying the message of adult support and the necessity of a youth-friendly environment. Youth and adults work together to coordinate trainings and provide technical 
assistance to the community prevention partnerships. For example, the regional office organizes two large scale networking sessions each year, publishes the coalition newsletter, and offers trainings on program evaluation and sustainability. Such experiences provide ample opportunities for youth to complete meaningful tasks while also learning and using new skills.

Through experience, the Seven Circles Coalition learned some important steps to fully integrate youth into the organization. The steps included providing multiple trainings for youth and adults involved in youth-adult partnerships, supporting projects initiated by youth, creating paid youth positions, allowing youth to co-facilitate training sessions, and changing organizational policies and procedures to allow youth to be involved.

Another example of successful youth engagement within an organization includes the Youth Advisory Committee (YAC) of the John Hopkins Center for Adolescent Health Promotion and Disease Prevention (Hohenemser \& Marshall, 2002). The YAC provides valuable insight in the planning, promotion, and implementation of community health initiatives. A mutually beneficial relationship exists between the Center's faculty members and YAC members. On one hand, faculty members rely on YAC members' ideas and feedback regarding the Center's work. Their suggestions help build awareness among faculty members regarding the health concerns and priorities of Baltimore's young people; thus providing them an important role at the Center with opportunities to complete meaningful tasks. On the other hand, membership in the YAC creates opportunities for young people to assume leadership roles, participate in training opportunities (e.g., time management and facilitation techniques), and organize specific projects for peers in their community where they have opportunities to learn and use new skills.

The results achieved by the YAC did not develop without a supporting organizational structure that facilitated youth engagement efforts. First, the Center demonstrated adult support by establishing respect and trust between adults and youth. Second, adults remained flexible when the YAC pursued new directions. Third, adults created a youth-friendly environment by providing youth with snacks at meetings and reimbursement for bus fares or cab rides.

\section{Conclusion}

Youth practitioners may enhance developmental opportunities for youth and improve program offerings by creating youth engagement opportunities within community teams. Youth, adults, and organizations may benefit from incorporating youth engagement efforts into their organizational structure. For example, youth may build social competences (Listen, Inc., 2003), adults may feel more energized, and organizational programs may become more effective in meeting the needs of program participants (Zeldin et al, 2000).

Four team characteristics that foster youth engagement were gleaned from the practitioner and research-based literature. The characteristics include adult support that conveys a respect for youth, a youth-friendly environment where youth feel welcomed and empowered, opportunities to complete meaningful tasks that advance team goals, and opportunities to learn and use new skills that build competencies. When coupled together these four team characteristics convey a strong message to youth that their involvement is an integral part of the team's work. Future research may involve effectiveness studies of teams' efforts to engage youth through these four team characteristics.

The field would also benefit by knowing the reasons why youth become involved (e.g., a personal passion or teacher recommendation) and its relationship to youth's level of 
involvement and effectiveness on the team. Moreover, mixed methods research (i.e., qualitative and quantitative methods) should be employed to examine these and other, not yet identified, characteristics and how they relate to retention of youth members as well as the contextual factors (e.g., neighborhood organization, team readiness, and poverty) that may mediate the relationship between youth and adult members.

Youth development practitioners who plan to incorporate youth engagement strategies into their organizational operations may begin by assessing the presence of the team characteristics discussed in this paper. Teams should identify characteristics that currently exist and characteristics that need to be further developed before youth are invited to join the team.

To facilitate the transition from an adult-only team structure to an adult-youth team structure, youth development practitioners should access resources on youth engagement that clearly articulate the steps to establish youth member positions (see Scheve, Perkins, Mincemoyer, \& Welsh, 2005; Young \& Sazama, 1999). These resources contain discussion questions, helpful tips, modifiable forms, and team activities to help translate the idea of youth engagement into manageable action steps for community teams. Using these resources will help youth development practitioners ensure that their well-meaning intentions behind youth engagement come to fruition in projects that provide benefits to youth, adults, and the communities being served.

\section{References}

Benson, P. (1997). All kids are our kids: What communities must do to raise caring and responsible children and adolescents. San Francisco CA: Jossey-Bass Publishers.

Bernard, H. (2004). The power of an untapped resource: Exploring youth representation on your board or committee. Juneau, AK: The Association of Alaska School Boards. Retrieved March 15, 2004 from http://www.aasb.org/Publications.html

Camino, L. (2000a). Putting youth-adult partnerships to work for community change: Lessons from volunteers across the country. Community Youth Development Journal, 1, 27-30.

Camino, L. (2000b). Youth-adult partnerships: New territory in community work and research. Applied Developmental Science, 4, 11-20.

Camino, L., \& Zeldin, S. (2002). Making the transition to community youth development: Emerging roles and competencies for youth- serving organizations and youth workers. In T. Burke, S.P. Curnan, J. Erickson, D.M. Hughes, N. Leon, R. Liem, K.J. Pittman, J. Terry, \& D. Woonteiler (Eds.), Community youth development anthology. Sudbury, MA: Institute for Just Communities, Brandeis University.

Cahill, M. (1997). Youth development and community development: Promises and challenges of convergence. Community \& Youth Development Series, Volume 2. Takoma Park, MD: The Forum for Youth Investment, International Youth Foundation.

Cargo, M., Grams, G., Ottoson, J., Ward, P., \& Green, L. (2003). Empowerment as fostering positive youth development and citizenship. Journal of Health Behavior, 27, S66-S79.

Checkoway, B., Richards-Schuster, K., Abdullah, S., Aragon, M., Facio, E., Figueroa, L., Reddy, E., Welsh, M., \& White, A. (2003). Young people as competent citizens. Community Development Journal, 28, 298-309. 
Curnan, S.P., \& Hughes, D.M. (2002). Towards shared prosperity: Change-making in the CYD movement. Community Youth Development Journal, 3, 25-33.

Eccles, J. \& Gootman, J.A. (2002). Community programs to promote youth development. Committee on Community-Level Programs for Youth. Board on Children, Youth, and Families, Commission on Behavioral and Social Sciences Education, National Research Council and Institute of Medicine. Washington, DC: Sage.

Fiscus, L. (2003). Youth as equal partners in decision making. The Education Digest, 68, 58-63.

Finn, J.L., \& Checkoway, B. (1998). Young people as competent community builders: A challenge to social work. Social Work, 43, 335-345.

Flanagan, C. \& Van Horn, B. (2003). Youth civic development: A logical next step in community youth development. In Villarruel, F.A., Perkins, D.F., Borden, L.M., \& Keith, J.G. (Eds.), Community Youth Development: Programs, policies, and practices (pp. 201-223). Thousand Oaks, CA: Sage Publications.

Ferrari, T.M. (2003). Working hand in hand: Community youth development and career development. In Villarruel, F.A., Perkins, D.F., Borden, L.M., \& Keith, J.G. (Eds.), Community Youth Development: Programs, policies, and practices (pp. 273-296). Thousand Oaks, CA: Sage Publications.

Hart, R. (1992). Children's participation: From tokenism to citizenship. Florence, Italy: International Child Development Center, UNIEF.

Hohenemser, L., \& Marshall, B. (2002). Utilizing a youth development framework to establish and maintain a youth advisory committee. Health Promotion Practice, 3, 155-165.

Huebner, A.J. (1998). Examining "empowerment": A how-to-guide for the youth development professional. Journal of Extension, 36. Retrieved Jan. 22, 2004 from http://www.joe.org/joe/1998december/a1.html

Hughes, D.M., \& Curnan, S.P. (2000). Community youth development: A framework for action. Community Youth Development Journal, 1, 7-11.

Hyman, J.B. (1999). Spheres of influence: A strategic synthesis \& framework for community youth development. Baltimore, MD: The Annie E. Casey Foundation.

Irby, M., Ferber, T., \& Pittman, K., Tolman, J., Yohalem, N. (2001). Youth action: Youth contributing to communities, communities supporting youth. Takoma Park, MD: Forum for Youth Investment, International Youth Foundation.

Jekielek, S.M., Moore, K.A., Hair, E.C., \& Scarupa, H.J. (2002). Mentoring: A promising strategy for youth development. Washington, DC: Child Trends.

Jones, K.R. (2004). An assessment of perceptions and experiences in community-based youth-adult partnerships. Unpublished doctoral dissertation, The Pennsylvania State University.

Jones, K.R. \& Perkins, D.F. (2005). Youth-adult partnerships. In C.B. Fisher \& R.M. Lerner (Eds.), Applied developmental science: An encyclopedia of research, policies, and programs (1159-1163). Thousand Oaks, CA: Sage. 
Kahne, J., Honig, M., \& Mclaughlin, M.W. (1998). The civic components of community youth development. New Designs for Youth Development, 14, 9-11.

Kirshner, B., O'Donoghue, J.L., \& McLaughlin, M. (2002). Youth participation: Improving institutions and communities. New Designs for Youth Development, 14.

Lane, R. (1996). On the journey to community youth development. New Designs for Youth Development, 12, 14-18.

Larson, R. (2000). Toward a psychology of positive youth development. American Psychologist, 55, 170-183.

Lauffer, A. (1982). Assessment tools: For practitioners, managers, and trainers. Beverly Hills, CA: Sage.

Lerner, R. (2004). Liberty: Thriving and civic engagement among America's youth. Thousand Oaks, CA: Sage.

Listen Inc., (2003). An emerging model for working with youth: Community organizing + youth development $=$ youth organizing. New York City, New York: Funders' Collaborative on Youth Organizing. Retrieved March 15, 2004 from http://www.fcyo.org/sitebody/resources.htm

Mitra, D.L. (2004). The significance of students: Can increasing "student voice" in schools lead to gains in youth development? Teachers College Record, 106, 651-688.

Mueller R.B., Wunrow, J.J., \& Einspruch, E.L. (2000). Providing youth services through youth-adult partnerships: A review of the literature. Reaching Today's Youth, 4, 37-48.

O’Donoghue, J.L., Kirshner, B., \& McLaughlin, M. (2002). Moving youth participation forward. New Directions for Youth Development, 96, 15-26.

Oldfather, P. (1995). Songs "come back most to them": Students experiences as researchers. Theory into Practice, 34, 131.

Pancer, S.M., Rose-Krasnor, L., \& Loiselle, L.D. (2002). Youth conferences as a context for engagement. New Directions for Youth Development, 96, 47-64.

Perkins, D.F., \& Borden, L.M. (2003). Key elements of community youth development. In Villarruel, F.A., Perkins, D.F., Borden, L.M., \& Keith, J.G. (Eds.), Community Youth Development: Programs, policies, and practices (pp. 327-340). Thousand Oaks, CA: Sage Publications.

Perkins, D.F. \& Borden L.M. (April, 2003). Spider web analysis for youth program. University Park, PA: Penn State Cooperative Extension.

Perkins, D.F., Borden, L.M., Keith, J.G., Hoope-Rooney, T.L., \& Villarruel, F.A. (2003). Community youth development: Partnership creating a positive world. In Villarruel, F.A., Perkins, D.F., Borden, L.M., \& Keith, J.G. (Eds.), Community Youth Development: Programs, policies, and practices (pp. 124). Thousand Oaks, CA: Sage Publications.

Rudduck, J., \& Futter, J. (2000). Pupil participation and perspective: 'Carving a new order of experience'. Cambridge Journal of Education, 30 (1), 75-89. 
Scheve, J.A., Perkins, D.F., Mincemoyer, C.C., Welsh, J.A. (2005). Say Y.E.S. to youth: Youth engagement strategies. University Park, PA; The Pennsylvania State University.

Wunrow, J.J., \& Einspruch, E.L. (2001). Promoting youth-adult partnerships: The seven circles coalition in Sitka, Alaska. The Journal of Primary Prevention, 22, 169- 185.

Yohalem, N. (2003). Adults who make a difference: Identifying the skills and characteristics of successful youth workers. In Villarruel, F.A., Perkins, D.F., Borden, L.M., \& Keith, J.G. (Eds.), Community Youth Development: Programs, policies, and practices (pp. 358-372). Thousand Oaks, CA: Sage Publications.

Young, K.S., \& Sazama, J. (1999). 14 Points: Successfully involving youth in decision making. Somerville, MA: Youth on Board.

Zeldin, S., McDaniel, A.K., Topitzes, D., \& Calvert, M. (2000). Youth in decision-making: A study on the impacts of youth on adults and organizations. Washington, DC: National 4-H Council.

Zeldin, S. (2004). Youth as agents of adult and community development: Mapping the processes and outcomes of youth engaged in organizational governance. Applied Developmental Science, 8, 75-90.

\section{Acknowledgement}

The authors wish to acknowledge the support of National Institute of Drug Abuse (1 R01 DA13709-01A1), Penn State University's Agricultural Experiment Station and Cooperative Extension Service. Address correspondence to: Daniel F. Perkins Ph.D., Associate Professor of Family and Youth Resiliency and Policy, The Pennsylvania State University, Department of Agricultural and Extension Education, 323 Agricultural Administration Building, University Park, PA 16802; email: dfp102@psu.edu

(C) Copyright of Journal of Youth Development Bridging Research and Practice. Content may not be copied or emailed to multiple sites or posted to a listserv without copyright holder's express written permission. Contact Editor at: patricia.dawson@oregonstate.edu for details. However, users may print, download or email articles for individual use.

ISSN 2325-4009 (Print); ISSN 2325-4017 (Online) 